A.D. Cousins and Daniel Derrin, eds. Shakespeare and the Soliloquy in Early Modern English Drama. Cambridge: Cambridge University Press, 2018. Pp. 278. Hardback $€ 75.00$. ISBN 9781107172548. https://doi. org/10.1017/9781316779118.

\title{
JOSHUA CALDICOTT
}

University of Nottingham/Shakespeare Institute

The soliloquy is an iconic aspect of early modern English drama, both as a device designed to engage with early modern audiences and as the form used in some of Shakespeare's most celebrated moments: from Hamlet's melancholic 'to be or not to be' to Juliet's lovelorn 'what's in a name'. Despite its significance, criticism has paid little attention to the form further than as a mode of rhetorical expression. A.D. Cousins and Daniel Derrin's edited collection addresses this lacuna with chapters covering questions of form and authorship, issues of politics and gender, and theories of performance and selfhood. The collection begins with an introduction analyzing examples from Marlowe's Doctor Faustus, Shakespeare's Julius Caesar, and Jonson's Volpone, teasing out various functions a soliloquy can perform and demonstrating how productive unpacking these speeches can be for understanding the wider ideological and structural concepts of their respective plays.

The first three chapters of the collection deal with the development of the pre-Shakespearean soliloquy, building a clear picture of the form's historical origins. Joseph A. Smith's opening chapter succinctly covers the breadth of Roman drama in relation to an antagonism towards theatre's inauthentic presentation of identity in order to consider how the soliloquy form was established (15-28). Using a spatial conception of performance in relation to genre, Smith compellingly identifies how comedy demonstrates personality and/or psychology beyond stock character, and how tragedies position characters in relation to nature and the cosmos. Raphael Falco then moves on to note the characteristics of an early Tudor soliloquy preceding the Renaissance form, highlighting key aspects of the soliloquy's increased centrality to narrative, its definition in terms of the speaker being alone with God/Reason, and its relationship to the audience (29-42). Having focused on the form's ability to build identity beyond stock characteristics, the collection then considers the soliloquy in relation to authorial style. The final preShakespearean chapter focuses on Christopher Marlowe's soliloquies, identifying a specific 'voice of selfhood against extinction' (43). Working through Marlowe's 
canon, L.E. Semler deftly examines how each play's soliloquies articulate a character's conflict, with particular care for their performative functions (43-55).

The collection continues to focus on authorial style, extending its discussion to Shakespeare's canon. As the central focus of the collection, these essays succeed in communicating the variety of ways in which Shakespeare deploys the soliloquy in different genres and through different voices. By defining the soliloquy in terms of the speaker's split self, Catherine Bates convincingly compares the 'castrated' subjectivity of classical female laments to the soliloquies of Marlowe's Dido, before relating this state to Shakespeare's various female soliloquists who respond to an existence outside of a phallic order (56-67). Daniel Derrin's chapter approaches comedic soliloquies, demonstrating the significance of their study by persuasively identifying characters' self-deception through humorously deformed versions of the period's rhetorical arts (68-79). By classifying orations as forensic (attempting to discover) and deliberative (attempting to persuade), Derrin argues that Benedick (of Much Ado) uses sententiae (proverbial phrases) to persuade himself out of other sententiae, and how he and Malvolio (of Twelfth Night) use enargeia (vivid descriptions) to imagine a reality that they can fool themselves into believing. Moving from comedies to histories, the late David Bevington's chapter proceeds through both tetralogies, insightfully demonstrating how the soliloquy constructs each major figure's identity (80-92). After appraising Richard III's self-construction across the first tetralogy, Bevington considers how Richard II's numerous soliloquies reveal his motivations in contrast to Bolingbroke/Henry IV whose lack of soliloquies avoids any admission of ambition. The chapter concludes by focusing on Falstaff's 'comic philosophizing' (88) in his soliloquies in contrast to Hal's construction of personal identity, at first in opposition to his company before it becomes more patriotic in the later plays. A.D. Cousins's chapter approaches Hamlet in relation to Francis Bacon's Of Truth (93-104). Cousins persuasively shows how Hamlet's remapping of his lost home through deformed classical analogues - centralized around his 'Hyperion' father — is comparable to Bacon's apprehension of the world achieved through his use of biblical authorities. Looking more broadly, Patrick Gray defines tragedy as 'a "collision" between opposing notions of good' (105), considering in his chapter how each major tragic hero battles the choice between shame culture and a desire to control, on the one hand, and guilt culture and Christian compassion, on the other; this approach comprehensively demonstrates how each protagonist takes the space of the soliloquy to pervert Christian moral reasoning for his own purposes (105-18). The final Shakespeare-focused chapter addresses the soliloquies of the late plays, as Kate Aughterson systematically works through this grouping to pinpoint Shakespeare's 
use of stylistic and grammatical features that affect style, tone, and even acting technique (119-38). By analyzing the high level of hypermetrical soliloquies that make speakers auricular figures - slowing down the speech to interrupt courtly discourse for moments of dramatic performative verse - Aughterson is able to account for the fantastical and poetic nature that critics often recognize in this grouping of plays.

The collection continues with its authorial focus by considering Shakespeare's contemporaries and successors, thus highlighting both Shakespeare and each respective playwright's perspective and use of the form. The first two chapters on Ben Jonson complement each other well, identifying an authorial style in his soliloquies that focuses on the art of performance to provoke audience reflection, either through insisting on its own being or as a way of constructing identity. Having noted Volpone's emphasis on the artistic genius of deceptive performances, James Loxley recognizes how both Poetaster and Sejanus frame the importance of the freedom of language in poetry, in recording history, and ultimately in Jonson's own drama (139-52). Brian Woolland then looks at the comedic soliloquy, focusing more on audience agency to see how spectators are drawn into siding or even working with devious tricksters like Volpone and Face (in Volpone and The Alchemist respectively), and how they are faced in turn with those such as Fitzdottrel and Pug (in The Devil is an Ass) who enact an identity they crave (153-66). With Andrew Hiscock's chapter on Thomas Middleton, it becomes all the more evident how the soliloquy functions as much more than a simple vehicle for individual self-actualization. Hiscock explores the form's use in The Revenger's Tragedy and The Lady's Tragedy to represent stage-life more broadly, as Middleton's rapid pace, simultaneous action, and expression of minor characters' desire for action give the form different functions (167-79). Moving into the Caroline period, Huw Griffith's work on John Ford's soliloquies cleverly demonstrates a change in the perception of the device within the Renaissance period (180-94). Griffiths identifies within the Caroline form an echo of Jacobean soliloquies reshaped into almost a stock rhetoric or gesture that is disrupted by the claustrophobic, frantic style of Caroline drama, which in turn violates the speech through frequent interruptions and eavesdroppers. The final author-centred chapter, by A.D. Cousins and Dani Napton, looks at William Davenant's Macbeth and the ways in which his Restoration adaptation shifts the soliloquy away from the personal (for which it has been widely criticized) to a more period relevant focus on political relationships, reshaping the play into a tragedy of state (195-204). In doing so, Cousins and Napton convincingly demonstrate Macduff's evolved role not simply as Macbeth's psychological foil but as a figure debating national versus individual loss. 
In place of a conclusion, the collection ends with a chapter by James Hirsh who empirically addresses the question of what constitutes a Renaissance soliloquy (205-24). Waiting until the end to attempt to conclusively define the soliloquy in many ways fits with the editors' initial motivation for chapters that 'cohere but do not necessarily agree with one another' (2), as each contributor defines their own understanding of the form, productively leading to a number of lively discussions. Hirsh's work is remarkable in its ability to categorically answer questions that have long been centres of debate, such as whether soliloquies and asides are vocalizations or thoughts. Unfortunately, Hirsh's determined, almost flippant tone belittles productive avenues of study. For example, Hirsh's assertion that scholars have 'blinded themselves' (217) to the evidence that soliloquies do not address the audience is contradicted by the wider collection itself: indeed, a consideration of the audience's role (perhaps as overhearers rather than addressees) is a significant and productive source of study within this book. Hirsh's empirical approach nevertheless draws impressive conclusions from his wide range of evidence, generally supporting the work of the preceding chapters.

This collection focuses on a variety of broad subjects - examining historical, performative, and philosophical concepts - yet each essay succeeds in its attempt to use the soliloquy to address wider questions within its respective area. Collectively, the essays effectively communicate with one another to give a broader picture of the culture of early modern English drama, revealing artistic development over time, the various playwrights' unique formal styles, and the wider historical socio-political thoughts that they express. A collection of this nature obviously could never be exhaustive, but it demonstrates the significant impact of focusing on short speeches such as the soliloquy. 